\title{
Stern-Layer Adsorption of Oligonucleotides on Lamellar Cationic Lipid Bilayer Investigated by Polarization-Resolved SFG-VS
}

\author{
Liqun Wang, ${ }^{\dagger, \dagger}$ Yang Shen, ${ }^{\dagger} \S$ Yanbo Yang, Wangting Lu, ${ }^{\dagger}$ Wenhui Li, ${ }^{\dagger}$ Feng Wei, ${ }^{\dagger}{ }^{\dagger}$ G Guang Zheng, \\ Youhua Zhou, ${ }^{\S}$ Wanquan Zheng, ${ }^{*} \dagger, \perp$ and Yuancheng Cao $\|$
}

${ }^{\dagger}$ Institution for Interdisciplinary Research, \& Key Laboratory of Optoelectronic Chemical Materials and Devices of Ministry of Education, ${ }^{\ddagger}$ College of Life Science, ${ }^{\S}$ School of Physics and Information Engineering, and "School of Chemical and Environmental Engineering, Jianghan University, 430056 Wuhan, Hubei, P. R. China

${ }^{\perp}$ Institut des Sciences Moléculaires d'Orsay, Université Paris-Sud, 91405 Orsay Cedex, France

\section{Supporting Information}

\begin{abstract}
The molecular interaction between the oligonucleotides and lipid membranes is the key to the functions of virus, aptamer, and various oligonucleotidebased materials. In this study, the conformational changes of oligonucleotides $\left(\mathrm{dT}_{25}\right)$ on lamellar cationic 1,2-dimyristoyl-3-trimethylammonium-propane (DMTAP) bilayer were investigated by polarization-resolved sum frequency generation vibrational spectroscopy (SFG-VS) in situ. The SFG-VS spectra within different wavenumber ranges were analyzed to give conformation details of thymine groups, phosphate groups, and $\mathrm{OD} / \mathrm{OH}$ groups and to provide a comprehensive and fundamental understanding of the oligonucleotide adsorption on a model bilayer. It is shown that the adsorption of $\mathrm{dT}_{25}$ on DMTAP bilayer reaches maximum at $C_{\mathrm{dT}} \approx 500 \mathrm{nM}$. And the conformation of $\mathrm{dT}_{25}$ molecules change significantly when surface charge of DMTAP bilayer reaches the point of zero charge (PZC) at $C_{\mathrm{dT}} \approx 100 \mathrm{nM}$. Combined spectroscopic evidences also indicate that the formation of electric double layer at the

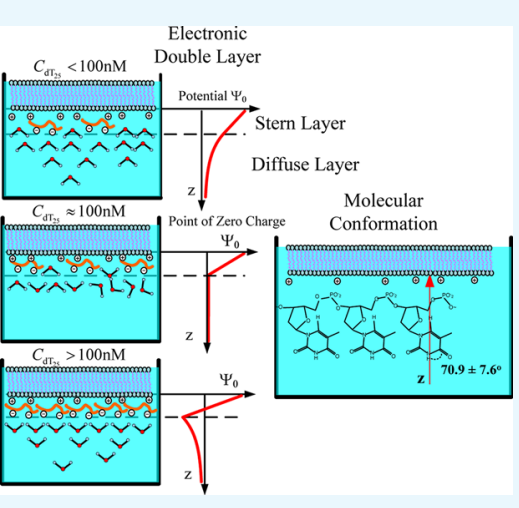
$\mathrm{DMTAP} / \mathrm{dT}_{25}$ surface follows the Gouy-Chapman-Stern model. The analysis results also show that the symmetric $\mathrm{PO}_{2}^{-}$stretching mode of oligonucleotide molecules can serve as a sensitive vibration molecular probe for quantifying the oligonucleotide/lipid charge ratio and determine the point of zero charge (PZC) of lipid bilayer surface, which may help researchers to control the layer-by-layer assembly of oligonucleotide-lipid complexes and to improve the efficiency genetic therapy against cancer and viral infections.
\end{abstract}

\section{INTRODUCTION}

The complexes formed by cationic lipid membrane and oligonucleotides have attracted extensive interest because of their applications in gene delivery as nonviral carriers of genetic material into living cells. ${ }^{1,2}$ The molecular interactions (forces) which assemble the oligonucleotides and lipid bilayers into complex but ordered lipoplexes are also the key to the functions of virus, aptamer, and various oligonucleotide-based materials. $^{2-6}$ The understanding of molecular interactions between lipid membrane and oligonucleotides will help researchers perform "bottom up" assemblies and build lipoplexes with equilibrium structures, which can ensure the safety and effectiveness of oligonucleotide-based materials during the gene therapy against the cancer and viral infections.

A number of experimental and theoretical studies have been conducted to comprehend the mechanism of formation of lipid bilayer-oligonucleotide complexes. ${ }^{1,7-9}$ Small-angle X-ray scattering (SAXS), ${ }^{1,9}$ stopped-flow spectrofluorometry, ${ }^{10-12}$ dynamic laser scattering (DLS), ${ }^{13,14}$ fluorescence resonance energy transfer, ${ }^{15-17}$ surface plasmon resonance, ${ }^{18,19}$ atomic force microscopy, ${ }^{20}$ cryotransmission electron microscopy, ${ }^{21,22}$ Fourier transform infrared spectroscopy, and Raman vibrational spectroscopy $^{23-25}$ were applied to investigate the lipoplex structures and kinetics of lipoplex formation. Theoretical modeling and simulation were also applied to understand the molecular driving force during the DNA adsorption. ${ }^{26,27}$ In general, the oligonucleotide-lipid bilayer complex formation can be described in three steps: the accumulation of anionic oligonucleotides on the cationic bilayer, the reverse/rupture of lipid vesicles, and the formation of aggregated multilamellar structure. It has been well established that the formation of lipoplex is driven by electrostatic attraction between the oppositely charged nucleic acid and lipids. Results of DLS and SAXS experiments also show that the size and $\zeta$ potential of liposomes can be tuned by lipid composition and the cationic lipid/DNA charge ratio, which may improve the transfection efficiency of the lipoplexes. ${ }^{28-31}$ Nevertheless, due to the limitations of characterizing methods, the interface/ surface specific information at the molecular level during the lipid-oligonucleotide interaction and lipoplex formation was hard to be obtained. The insights of accumulation/adsorption of oligonucleotide at molecular level are required to control the

Received: August 19, 2017

Accepted: November 29, 2017

Published: December 27, 2017 

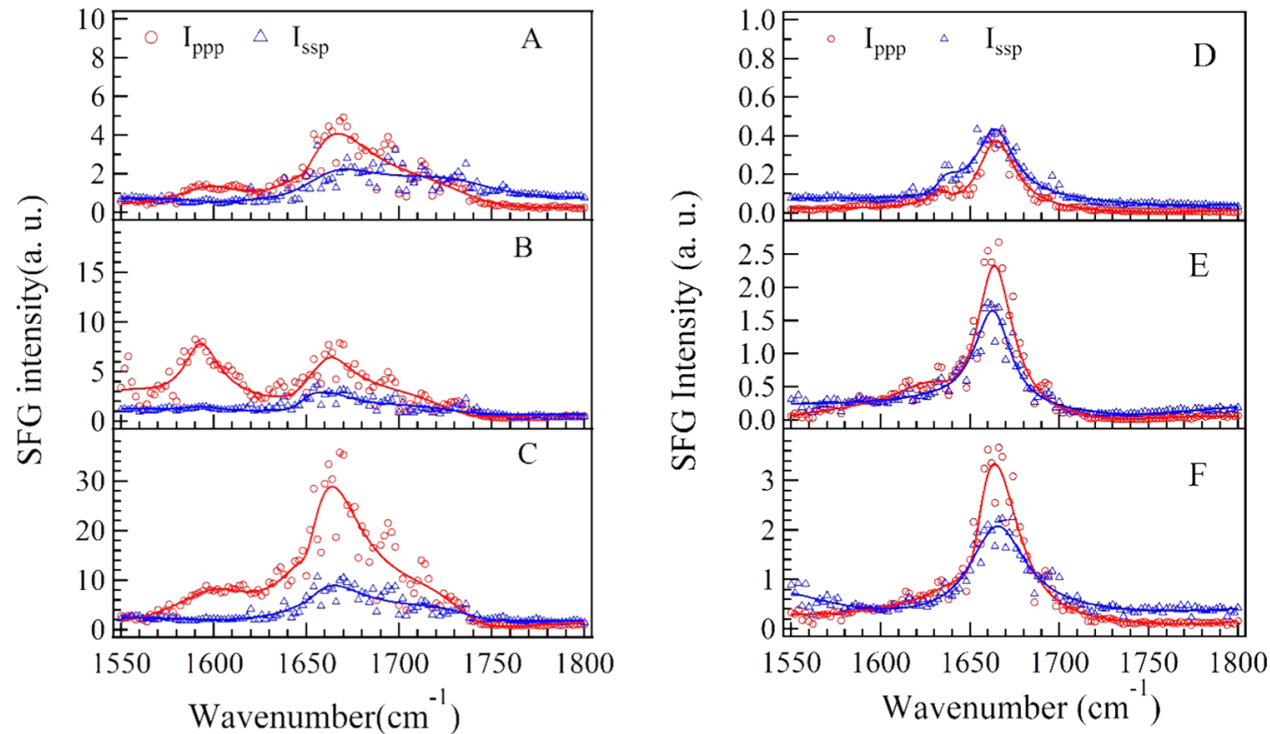

Figure 1. SFG spectra collected in the wavenumber range of $1550-1800 \mathrm{~cm}^{-1}$ at different concentrations of $\mathrm{dT}_{25}\left(C_{\mathrm{dT}}\right)$. (A) $C_{\mathrm{dT}}=50 \mathrm{nM}$ in $\mathrm{H}_{2} \mathrm{O}$; (B) $C_{\mathrm{dT}}=100 \mathrm{nM}$ in $\mathrm{H}_{2} \mathrm{O}$; (C) $C_{\mathrm{dT}}=250 \mathrm{nM}$ in $\mathrm{H}_{2} \mathrm{O}$; (D) $C_{\mathrm{dT}}=50 \mathrm{nM}$ in $\mathrm{D}_{2} \mathrm{O}$; (E) $C_{\mathrm{dT}}=100 \mathrm{nM}$ in $\mathrm{D}_{2} \mathrm{O}$; (F) $C_{\mathrm{dT}}=100 \mathrm{nM}$ in $\mathrm{D}_{2} \mathrm{O}$.

successive events of charge reversing, vesicle rupturing, and multilamellar lipoplex formation.

Sum frequency generation vibrational spectroscopy (SFGVS) has been successfully applied as an interface-specific probe to investigate the molecular structure and kinetics at biointerfaces. $^{32-39}$ Recent progresses prove that SFG-VS is also very useful for abstracting the structural and conformational information from the interfacial anchored oligonucleotides. $^{40-47}$ The structure of single-stranded DNA monolayers on platinum substrate was investigated by Sartenaer et al. using SFG-VS. ${ }^{40}$ The divalent metal ion-induced deformation of DNA monolayer was also investigated by Asanuma et al. using SFG-VS and X-ray photoelectron spectroscopy. ${ }^{41}$ Ionoligonucleotide interactions were also investigated extensively by Geiger's group using multiple nonlinear optical techniques, such as SFG-VS and second harmonic generation. ${ }^{42,43}$ The structural differences between oligonucleotide films in air and under various aqueous situations were also characterized by Howell et al. ${ }^{44,45}$ SFG-VS was also applied to investigate the interactions between oligonucleotides and model lipid membranes. A pioneer work, which investigated the interaction between the cationic lipid monolayer and $\lambda$-phage DNA molecules by monitoring the OD signals within the wavenumber range of $2000-2700 \mathrm{~cm}^{-1}$, was carried out by Wurpel et $\mathrm{al}^{46}$ By focusing on the SFG spectra in the wavenumber range of $1200-1800 \mathrm{~cm}^{-1}$, the interfacial conformation and Gquadruplex forming kinetics of G-rich oligonucleotides on 1,2dimyristoyl-3-trimethylammonium-propane (DMTAP) lipid bilayers were also elucidated by Wei et al. ${ }^{47}$ In spite of these previous investigations, the conformational and kinetic properties of oligonucleotides during the adsorption/interaction remain elusive. For instance, Wurpel et al.'s results indicate significant reconstruction of surface water molecules during the DNA-lipid interaction, which can account for the Langmuir adsorption of DNA molecules. ${ }^{46}$ However, the conformation changes of oligonucleotide molecules during such adsorption are still unclear.

In the current study, the spectra of $\mathrm{dT}_{25}-\mathrm{DMTAP}$ bilayer complexes were collected by the polarization-resolved SFG-VS system in situ. The SFG spectra detected within different wavenumber regions can provide conformational details of different molecular groups, such as phosphate, thymine, and deoxyribose groups, thus facilitating the elucidation of the molecular mechanism of $\mathrm{dT}_{25}$ molecule-membrane interaction.

\section{RESULTS AND DISCUSSION}

2.1. SFG Spectra in $\mathrm{H}_{2} \mathrm{O}$ and $\mathrm{D}_{2} \mathrm{O}$ and Peak Assignments. Figure 1 shows the ppp and ssp spectra in the wavenumber range of $1550-1800 \mathrm{~cm}^{-1}$ at various concentration of $\mathrm{dT}_{25}$ after the $\mathrm{dT}_{25}$-DMTAP bilayer interaction. Several characteristic peaks at $\sim 1600 \mathrm{~cm}^{-1}\left(\mathrm{NH}_{2}\right.$ bending mode of tris buffer), $\sim 1650 \mathrm{~cm}^{-1}$ (thymine $\mathrm{C}_{4}=\mathrm{O}$ and $\mathrm{C}_{5}=$ $\mathrm{C}_{6}$ out-of-phase $180^{\circ}$ stretching mode), $\sim 1660 \mathrm{~cm}^{-1}$ (thymine $\mathrm{C}_{4}=\mathrm{O}$ and $\mathrm{C}_{5}=\mathrm{C}_{6}$ in-phase $0^{\circ}$ stretching mode), and $\sim 1730$ $\mathrm{cm}^{-1}$ (thymine $\mathrm{C}_{2}=\mathrm{O}$ stretching mode) can be observed in Figure $1 \mathrm{~A}-\mathrm{C}$ (see Table 1 for details). ${ }^{48,49}$ As shown in Figure $3 \mathrm{~A}-\mathrm{C}$, the peak intensities of $\mathrm{C}_{4}=\mathrm{O}$ and $\mathrm{C}_{5}=\mathrm{C}_{6}$ in-phase $0^{\circ}$ stretching mode increase gradually as $C_{\mathrm{dT}}$ increases to $250 \mathrm{nM}$

Table 1. Spectra Assignments of $\mathbf{d T}_{25}$ Molecules

\begin{tabular}{|c|c|}
\hline peaks $\left(\mathrm{cm}^{-1}\right)$ & assignments $^{a}$ \\
\hline$\sim 1060$ & ribose $\mathrm{C}-\mathrm{C}$ stretching \\
\hline$\sim 1090$ & $\mathrm{PO}_{2}^{-}$symmetric stretching \\
\hline$\sim 1150$ & ribose $\mathrm{C}-\mathrm{O}-\mathrm{C}$ stretching \\
\hline$\sim 1600$ & tris $\delta-\mathrm{NH}_{2}$ bending \\
\hline$\sim 1650$ & $\mathrm{dT} \mathrm{C}_{4}=\mathrm{O}$ and $\mathrm{C}=\mathrm{C}$ out-of phase \\
\hline$\sim 1660$ & $\mathrm{dT} \mathrm{C}_{4}=\mathrm{O}$ and $\mathrm{C}=\mathrm{C}$ in-phase \\
\hline$\sim 1730$ & $\mathrm{C}_{2}=\mathrm{O}$ stretching \\
\hline$\sim 2350$ & OD stretching of $\mathrm{D}_{2} \mathrm{O}$ \\
\hline \multicolumn{2}{|l|}{$\sim 2550$} \\
\hline \multicolumn{2}{|l|}{$\sim 2720$} \\
\hline$\sim 3060$ & $\mathrm{dT} \mathrm{C}_{6}-\mathrm{H}$ stretching \\
\hline$\sim 3140$ & $\mathrm{dT} \mathrm{N}_{3}-\mathrm{H}$ stretching \\
\hline$\sim 3200$ & $\mathrm{OH}$ stretching of $\mathrm{H}_{2} \mathrm{O}$, dT, and tris molecules \\
\hline$\sim 3400$ & \\
\hline$\sim 3600$ & \\
\hline
\end{tabular}

${ }^{a}$ Check Figure S6 for the corresponding atoms of thymidine molecule. 
due to the adsorption of $\mathrm{dT}_{25}$ molecules on DMTAP bilayers. The peak position of $\mathrm{NH}_{2}$ bending mode is significantly redshifted to $1592 \mathrm{~cm}^{-1}$ at $C_{\mathrm{dT}}=100 \mathrm{nM}$ (fitting parameters are listed in Table 2), which indicates that the hydrogen-bonding

Table 2. Fitting Parameters Calculated from Figure 1A-C $\left(\mathrm{H}_{2} \mathrm{O}\right)$ and Figure $1 \mathrm{D}-\mathrm{F}\left(\mathrm{D}_{2} \mathrm{O}\right)$

\begin{tabular}{|c|c|c|c|c|c|c|}
\hline & \multicolumn{2}{|c|}{$50 \mathrm{nM}$} & \multicolumn{2}{|c|}{$100 \mathrm{nM}$} & \multicolumn{2}{|c|}{$250 \mathrm{nM}$} \\
\hline & $I_{\mathrm{ppp}}$ & $I_{\mathrm{ssp}}$ & $I_{\mathrm{ppp}}$ & $I_{\mathrm{ssp}}$ & $I_{\mathrm{ppp}}$ & $I_{\text {ssp }}$ \\
\hline & & & $\mathrm{H}_{2} \mathrm{O}$ & & & \\
\hline$A_{0}$ & 0.00 & 0.00 & 0.00 & 0.00 & 0.00 & 0.00 \\
\hline$B_{0}$ & 0.48 & 0.84 & 1.06 & 0.73 & 1.41 & 1.42 \\
\hline$\chi_{1}$ & 0.6 & -0.1 & 1.3 & 0.2 & 1.3 & -0.2 \\
\hline$\omega_{1}$ & 1599.0 & & 1592.2 & & 1602.1 & \\
\hline$\tau_{1}$ & 22.0 & 11.6 & 25.9 & & & \\
\hline$\chi_{2}$ & -0.2 & 0.0 & -0.8 & 0.5 & -0.8 & -0.1 \\
\hline$\omega_{2}$ & 1648.8 & & 1650.8 & & 1650.3 & \\
\hline$T_{2}$ & 6.6 & 8.6 & 6.6 & & & \\
\hline$\chi_{3}$ & 1.6 & 0.7 & 4.3 & 0.5 & 4.3 & 1.7 \\
\hline$\omega_{3}$ & 1661.1 & & 1660.3 & & 1660.2 & \\
\hline$\tau_{3}$ & 22.9 & & 12.9 & & 19.9 & \\
\hline$\chi_{4}$ & -1.4 & -2.2 & -3.3 & -1.7 & -3.3 & -3.3 \\
\hline$\omega_{3}$ & 1735.6 & & 1728.8 & & 1734.7 & \\
\hline$\tau_{3}$ & 35.3 & & 31.8 & & 24.7 & \\
\hline$\chi_{\mathrm{NR}}$ & -4.46 & 1.87 & $\begin{array}{l}2.63 \\
\mathrm{D}_{2} \mathrm{O}\end{array}$ & 3.93 & 5.63 & 8.02 \\
\hline$A_{0}$ & -0.08 & 0.03 & -0.07 & -0.01 & 0.00 & -0.04 \\
\hline$B_{0}$ & 0.19 & 0.27 & 0.43 & 0.43 & -0.40 & -0.20 \\
\hline$\chi_{1}$ & -0.2 & -3.1 & 7.5 & 0.3 & -20.3 & 0.0 \\
\hline$\omega_{1}$ & 1635.0 & & 1630.8 & & 1653.1 & \\
\hline$\tau_{1}$ & 7.4 & & 22.1 & & 8.5 & \\
\hline$\chi_{2}$ & 1.0 & 0.8 & 1.7 & & 1.7 & 0.9 \\
\hline$\omega_{2}$ & 1663.9 & & 1663.1 & & 1664.6 & \\
\hline$T_{2}$ & 12.8 & & 12.6 & & 18.5 & \\
\hline$\chi_{3}$ & 1.0 & 0.2 & 1.4 & -3.8 & 1.4 & 3.3 \\
\hline$\omega_{3}$ & 1759.7 & & 1750.0 & & 1804.3 & \\
\hline$\tau_{3}$ & 113.7 & & 50.6 & & 54.2 & \\
\hline$\chi_{\mathrm{NR}}$ & 0.00 & 0.04 & -0.23 & 0.05 & 0.08 & 0.32 \\
\hline
\end{tabular}

strength is significantly weakened. ${ }^{53}$ On the other hand, the peak width of $\mathrm{C}_{4}=\mathrm{O}$ and $\mathrm{C}_{5}=\mathrm{C}_{6}$ in-phase $0^{\circ}$ stretching mode is significantly narrowed (from 22 to $12 \mathrm{~cm}^{-1}$ ) at $C_{\mathrm{dT}}=100$ $\mathrm{nM}$, which indicates that thymine group of $\mathrm{dT}_{25}$ molecules forms a more compacted conformation at such concentration.

As to the $\mathrm{dT}_{25}$ molecules in $\mathrm{D}_{2} \mathrm{O}$ solution, the intensities of SFG spectra shown in Figure $1 \mathrm{D}, \mathrm{F}$ are only $1 / 10$ of those shown in Figure 1A,C. The peak intensities of thymine $\mathrm{C}_{2}=\mathrm{O}$ stretching mode may decrease significantly due to the weaker hydrogen-bonding strength in $\mathrm{D}_{2} \mathrm{O}$ solution. ${ }^{49}$ The peak intensity of tris buffer $\mathrm{NH}_{2}$ bending mode and thymine $\mathrm{C}_{2}=$ $\mathrm{O}$ stretching mode are not clearly shown in Figure $1 \mathrm{D}-\mathrm{F}$. The frequency of $\mathrm{NH}_{2}$ bending is usually red-shifted (out of this wavenumber range) because the $\mathrm{NH}_{2}$ group was replaced by the $\mathrm{ND}_{2}$ group in $\mathrm{D}_{2} \mathrm{O}$ solution. ${ }^{50}$ The peak widths (9-18 $\mathrm{cm}^{-1}$ ) of $\mathrm{C}_{4}=\mathrm{O}$ and $\mathrm{C}_{5}=\mathrm{C}_{6}$ in-phase $0^{\circ}$ stretching mode shown in Figure 3D-F are much lower than the peak widths $\left(19-27 \mathrm{~cm}^{-1}\right.$ ) shown in Figure 3A-C (fitting parameters are listed in Table 3). Such spectra characteristics indicate that thymine groups of $\mathrm{dT}_{25}$ oligonucleotide chain in $\mathrm{D}_{2} \mathrm{O}$ solution may adopt a more compacted conformation comparing to the thymine groups in $\mathrm{H}_{2} \mathrm{O}$ solution. Such difference in DNA conformations may be induced by the weaker hydrogen-
Table 3. Fitting Parameters Calculated from Figure 2A-C $\left(\mathrm{H}_{2} \mathrm{O}\right)$ and Figure $2 \mathrm{D}-\mathrm{F}\left(\mathrm{D}_{2} \mathrm{O}\right)$

\begin{tabular}{|c|c|c|c|c|c|c|}
\hline & \multicolumn{2}{|c|}{$50 \mathrm{nM}$} & \multicolumn{2}{|c|}{$100 \mathrm{nM}$} & \multicolumn{2}{|c|}{$250 \mathrm{nM}$} \\
\hline & $I_{\mathrm{ppp}}$ & $I_{\mathrm{ssp}}$ & $I_{\mathrm{ppp}}$ & $I_{\mathrm{ssp}}$ & $I_{\mathrm{ppp}}$ & $I_{\text {ssp }}$ \\
\hline \multicolumn{7}{|c|}{$\mathrm{H}_{2} \mathrm{O}$} \\
\hline$A_{0}$ & -0.26 & 0.22 & 0.92 & -0.11 & -0.21 & 0.20 \\
\hline$B_{0}$ & 0.14 & -0.31 & -1.11 & -0.05 & 0.27 & 0.36 \\
\hline$\chi_{1}$ & -0.38 & 0.35 & 0.52 & 0.15 & 0.19 & 0.00 \\
\hline$\omega_{1}$ & 1069.1 & & 1057.1 & & 1055.9 & \\
\hline$\tau_{1}$ & 4.8 & & 28.0 & & 19.4 & \\
\hline$\chi_{2}$ & -0.56 & 1.06 & 0.15 & -0.36 & -0.05 & 0.24 \\
\hline$\omega_{2}$ & 1090.5 & & 1094.6 & & 1092.6 & \\
\hline$T_{2}$ & 9.1 & & 9.1 & & 9.1 & \\
\hline$\chi_{3}$ & & & & & 0.62 & -0.11 \\
\hline$\omega_{3}$ & & & & & 1156.1 & \\
\hline$\tau_{3}$ & & & & & 54.1 & \\
\hline$\chi_{\mathrm{NR}}$ & -0.56 & 0.00 & -0.08 & 0.02 & -0.10 & -0.03 \\
\hline & & & $\mathrm{D}_{2} \mathrm{O}$ & & & \\
\hline$A_{0}$ & 0.13 & 0.19 & -0.10 & -0.10 & -0.03 & -0.18 \\
\hline$B_{0}$ & 0.01 & -0.10 & -0.05 & -0.35 & 0.00 & -0.03 \\
\hline$\chi_{1}$ & 0.22 & -0.02 & 0.31 & 1.04 & 0.46 & 0.64 \\
\hline$\omega_{1}$ & 1045.1 & & 1059.8 & & 1057.5 & \\
\hline$\tau_{1}$ & 6.7 & & 6.9 & & 10.1 & \\
\hline$\chi_{2}$ & 0.23 & 0.61 & -0.19 & -0.36 & 0.10 & -1.28 \\
\hline$\omega_{2}$ & 1094.0 & & 1087.4 & & 1092.8 & \\
\hline$T_{2}$ & 12.6 & & 10.2 & & 10.7 & \\
\hline$\chi_{3}$ & 0.10 & 0.17 & 0.04 & -0.04 & -0.04 & -0.13 \\
\hline$\omega_{3}$ & 1154.9 & & 1134.2 & & 1152.1 & \\
\hline$\tau_{3}$ & 6.0 & & 11.3 & & 6.7 & \\
\hline$\chi_{\mathrm{NR}}$ & 0.02 & 0.00 & -0.01 & -0.12 & 0.04 & -0.01 \\
\hline
\end{tabular}

bonding strength in $\mathrm{D}_{2} \mathrm{O}$ solution comparing to that in $\mathrm{H}_{2} \mathrm{O}$ solution due to the isotope effect. It has been reported that hydrogen-bonding environment is very essential for maintaining the oligonucleotide conformations: the stronger hydrogenbonding environment will enhance the ordering of the nucleotide groups, and the weakening of hydrogen-bonding environment will lead to a collapsed conformation of oligonucleotides. $^{50,51}$ Previous electron microscopy experiments also indicate that the thermal denaturation temperature of DNA molecules in $\mathrm{H}_{2} \mathrm{O}$ solution is slightly lower than that in $\mathrm{D}_{2} \mathrm{O}$ solution. ${ }^{52}$

Figure 2 shows the $I_{\mathrm{ppp}}$ and $I_{\mathrm{ssp}}$ spectra in the wavenumber range of $1000-1200 \mathrm{~cm}^{-1}$ at various concentrations of $\mathrm{dT}_{25}$ after $\mathrm{dT}_{25}-\mathrm{DMTAP}$ bilayers interaction. As seen in Figure 2, several characteristic peaks at $\sim 1060 \mathrm{~cm}^{-1}$ (deoxyribose C-C stretching), $\sim 1090 \mathrm{~cm}^{-1}$ (symmetric $\mathrm{PO}_{2}{ }^{-}$stretching), and $\sim 1150 \mathrm{~cm}^{-1}$ (deoxyribose $\mathrm{C}-\mathrm{O}-\mathrm{C}$ stretching) are shown in Figure $2 \mathrm{~A}-\mathrm{F} .^{53}$

The peak position of symmetric $\mathrm{PO}_{2}^{-}$stretching mode in $\mathrm{H}_{2} \mathrm{O}$ solution is significantly red-shifted at $C_{\mathrm{dT}}=50 \mathrm{nM}$, and the peak position of symmetric $\mathrm{PO}_{2}{ }^{-}$stretching mode in $\mathrm{D}_{2} \mathrm{O}$ solution is significantly red-shifted at $C_{\mathrm{dT}}=100 \mathrm{nM}$. The peak width of symmetric $\mathrm{PO}_{2}{ }^{-}$stretching mode in $\mathrm{H}_{2} \mathrm{O}$ solution is slightly smaller than that in $\mathrm{D}_{2} \mathrm{O}$ solution. However, the changes of the peak amplitudes of deoxyribose $\mathrm{C}-\mathrm{C}$ stretching and deoxyribose $\mathrm{C}-\mathrm{O}-\mathrm{C}$ stretching seem unpatented (shown in Figures S2 and S4).

Figure 3 shows the susceptibilities $\left(\left|\chi^{(2)}\right|=\left|A_{\mathrm{q}} / \Gamma_{\mathrm{q}}\right|\right)$ and center wavenumbers $\left(\omega_{0, \mathrm{q}}\right)$ fitted from the SFG spectra in different wavenumber ranges (Figures S1-S4). As shown in Figure $3 \mathrm{~A}, \mathrm{~B}$, the susceptibilities $\left(\chi_{\mathrm{ppp}}^{(2)}\right.$ and $\left.\chi_{\mathrm{ssp}}^{(2)}\right)$ of thymine 

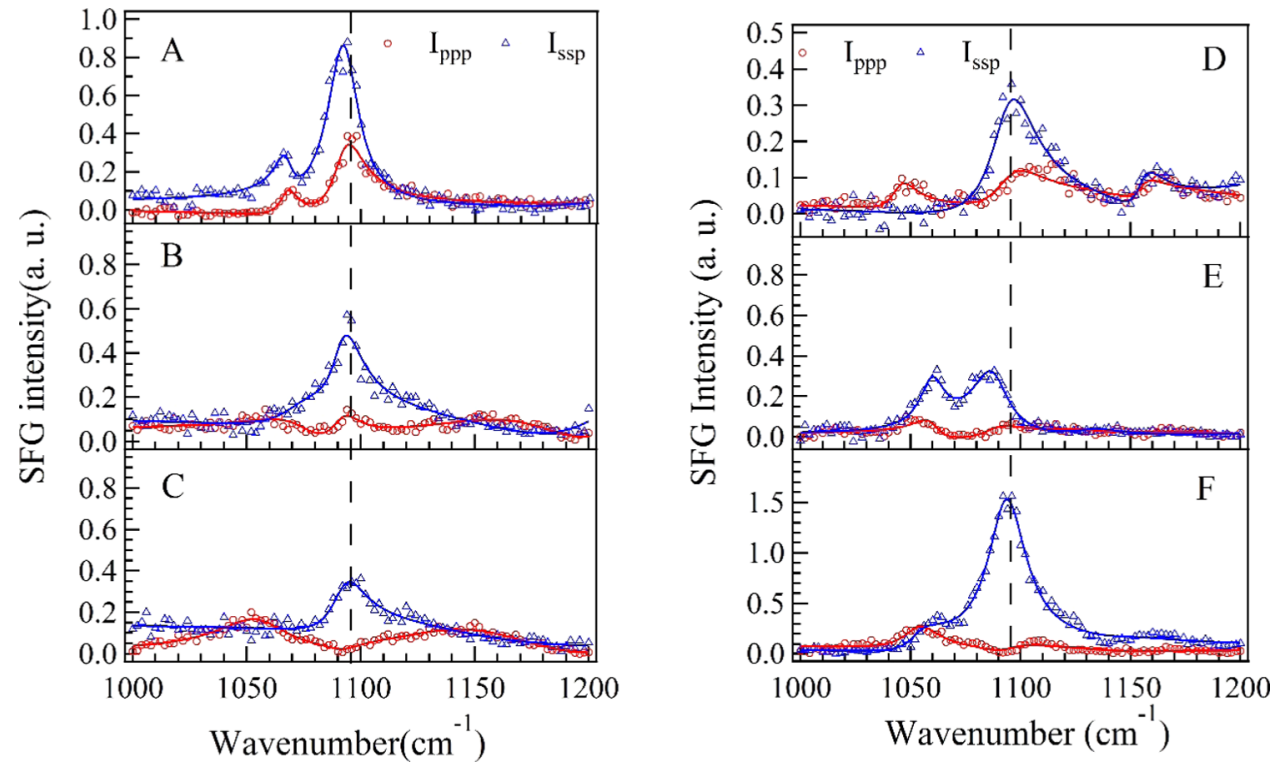

Figure 2. SFG spectra of DMTAP bilayers in the wavenumber range of $1000-1200 \mathrm{~cm}^{-1}$ at different $C_{\mathrm{dT}}$. (A) $C_{\mathrm{dT}}=50 \mathrm{nM}$ in $\mathrm{H}_{2} \mathrm{O}$; $(\mathrm{B}) C_{\mathrm{dT}}=100$ $\mathrm{nM}$ in $\mathrm{H}_{2} \mathrm{O}$; (C) $C_{\mathrm{dT}}=250 \mathrm{nM}$ in $\mathrm{H}_{2} \mathrm{O}$; (D) $C_{\mathrm{dT}}=50 \mathrm{nM}$ in $\mathrm{D}_{2} \mathrm{O}$; (E) $C_{\mathrm{dT}}=100 \mathrm{nM}$ in $\mathrm{D}_{2} \mathrm{O}$; (F) $C_{\mathrm{dT}}=250 \mathrm{nM}$ in $\mathrm{D}_{2} \mathrm{O}$.
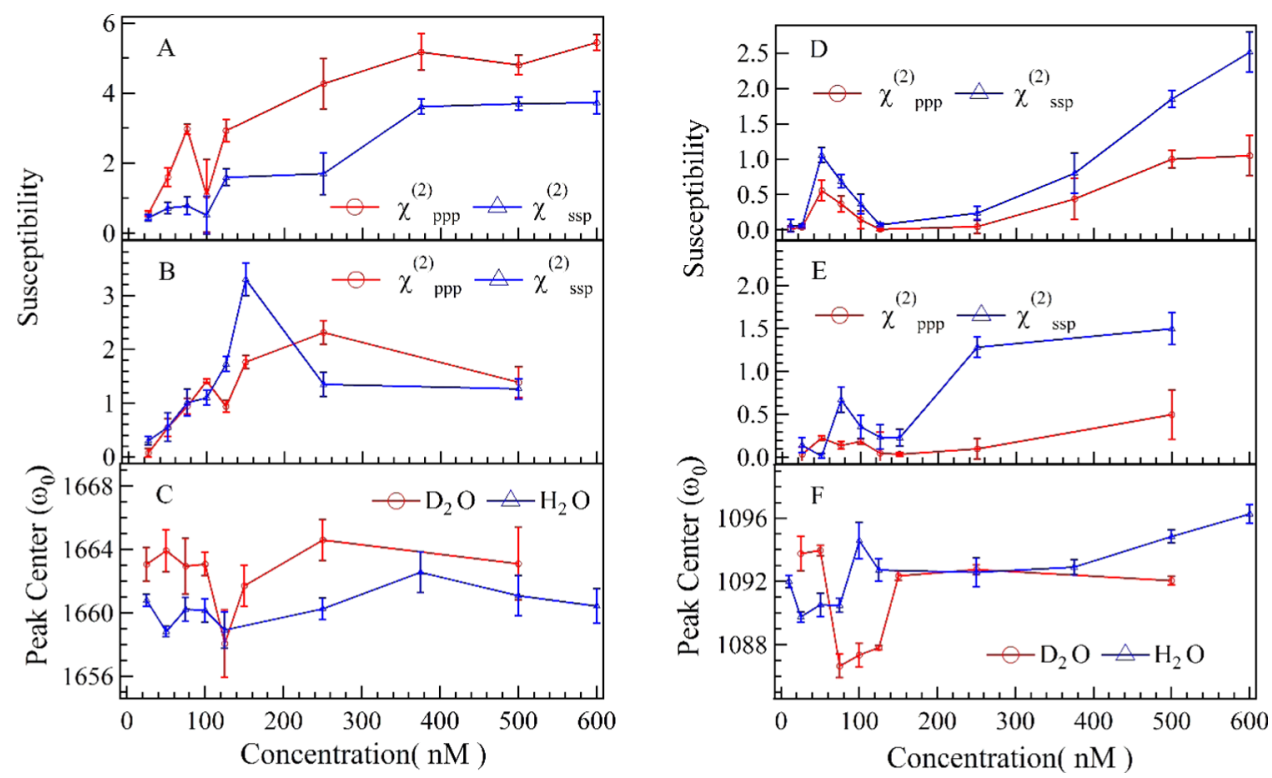

Figure 3. Concentration dependence of SFG susceptibilities $\left(\left|\chi^{(2)}\right|=\mid A_{\mathrm{q}} / \Gamma_{\mathrm{q}}\right)$ and peak center wavenumbers $\left(\omega_{0}\right)$ of thymine groups $(\mathrm{A}-\mathrm{C})$ and $\mathrm{PO}_{2}^{-}$groups $(\mathrm{D}-\mathrm{F}) .(\mathrm{A}) \chi_{\mathrm{ppp}}^{(2)}$ and $\chi_{\text {ssp }}^{(2)}$ of $\mathrm{C}_{4}=\mathrm{O}$ and $\mathrm{C}_{5}=\mathrm{C}_{6}$ in-phase $0^{\circ}$ stretching mode in $\mathrm{H}_{2} \mathrm{O}$ solutions; (B) $\chi_{\mathrm{ppp}}^{(2)}$ and $\chi_{\text {ssp }}^{(2)}$ of $\mathrm{C}_{4}=\mathrm{O}$ and $\mathrm{C}_{5}=$ $\mathrm{C}_{6}$ in-phase $0^{\circ}$ stretching mode in $\mathrm{D}_{2} \mathrm{O}$ solutions; (C) $\omega_{0}$ of $\mathrm{C}_{4}=\mathrm{O}$ and $\mathrm{C}_{5}=\mathrm{C}_{6}$ in-phase $0^{\circ}$ stretching mode in $\mathrm{H}_{2} \mathrm{O}$ and $\mathrm{D}_{2} \mathrm{O}$ solutions; (D) $\chi_{\mathrm{ppp}}^{(2)}$ and $\chi_{\text {ssp }}^{(2)}$ of symmetric $\mathrm{PO}_{2}^{-}$stretching mode in $\mathrm{H}_{2} \mathrm{O}$ solutions; (E) $\chi_{\mathrm{ppp}}^{(2)}$ and $\chi_{\text {ssp }}^{(2)}$ of symmetric $\mathrm{PO}_{2}{ }^{-}$stretching mode in $\mathrm{D}_{2} \mathrm{O}$ solutions; (F) $\omega_{0}$ of symmetric $\mathrm{PO}_{2}^{-}$stretching mode.

groups increase as $C_{\mathrm{dT}}$ increases and reach a maximum value at $C_{\mathrm{dT}}=600 \mathrm{nM}$ in $\mathrm{H}_{2} \mathrm{O}$ solution and $\mathrm{C}_{\mathrm{dT}}=500 \mathrm{nM}$ in $\mathrm{D}_{2} \mathrm{O}$ solution. As to the $\mathrm{PO}_{2}{ }^{-}$groups (Figure $3 \mathrm{D}, \mathrm{E}$ ), the curves of susceptibilities in $\mathrm{H}_{2} \mathrm{O}$ solution and $\mathrm{D}_{2} \mathrm{O}$ solution show a significant increase at $C_{\mathrm{dT}} \approx 100 \mathrm{nM}$, which indicates that ordering or surface abundance of $\mathrm{PO}_{2}^{-}$groups is improved at such concentration. However, the values of $\chi_{\mathrm{ppp}, \mathrm{PO}_{2}^{-}}^{(2)}$ and $\chi_{\mathrm{ssp}, \mathrm{PO}_{2}^{-}}^{(2)}$ are showing ongoing increases at $C_{\mathrm{dT}}=600$ and $500 \mathrm{nM}$. On the other hand, it is also easy to note that the peaks of thymine $\mathrm{C}_{4}=\mathrm{O}$ and $\mathrm{C}_{5}=\mathrm{C}_{6}$ in-phase $0^{\circ}$ stretching mode and symmetric $\mathrm{PO}_{2}^{-}$stretching mode at $C_{\mathrm{dT}} \approx 100 \mathrm{nM}$ (Figure $3 \mathrm{C}, \mathrm{F}$ ) in both $\mathrm{D}_{2} \mathrm{O}$ solution and $\mathrm{H}_{2} \mathrm{O}$ solution are significantly red-shifted comparing to those observed at other concen- trations. The fitted parameters indicate that the peak position of thymine $\mathrm{C}_{4}=\mathrm{O}$ and $\mathrm{C}_{5}=\mathrm{C}_{6}$ in-phase $0^{\circ}$ stretching $\left(\omega_{0}^{\text {Thymine }}\right)$ is red-shifted $\sim 4 \mathrm{~cm}^{-1}$ in $\mathrm{H}_{2} \mathrm{O}$ and $\sim 7 \mathrm{~cm}^{-1}$ in $\mathrm{D}_{2} \mathrm{O}$ at $C_{\mathrm{dT}}=$ $100 \mathrm{nM}$. And the peak position of symmetric $\mathrm{PO}_{2}^{-}$stretching $\left(\omega_{0}^{\mathrm{PO}_{2}^{-}}\right)$is red-shifted $\sim 3 \mathrm{~cm}^{-1}$ in $\mathrm{H}_{2} \mathrm{O}$ and $\sim 6 \mathrm{~cm}^{-1}$ in $\mathrm{D}_{2} \mathrm{O}$ at $C_{\mathrm{dT}}=75 \mathrm{nM}$. Such red shifts of both peaks indicate that local environments around the $\mathrm{PO}_{2}{ }^{-}$groups and thymine groups at $C_{\mathrm{dT}} \approx 100 \mathrm{nM}$ are very different from the local environments at other concentrations. ${ }^{33}$

2.2. Adsorption Model for $\mathbf{d T}_{25}$ Molecules. To understand the influence of local environment changes at different $C_{\mathrm{dT}}$ values and to clarify the IR assignment, the SFG spectra of both $\mathrm{OH}$ stretching modes and $\mathrm{OD}$ stretching modes were 

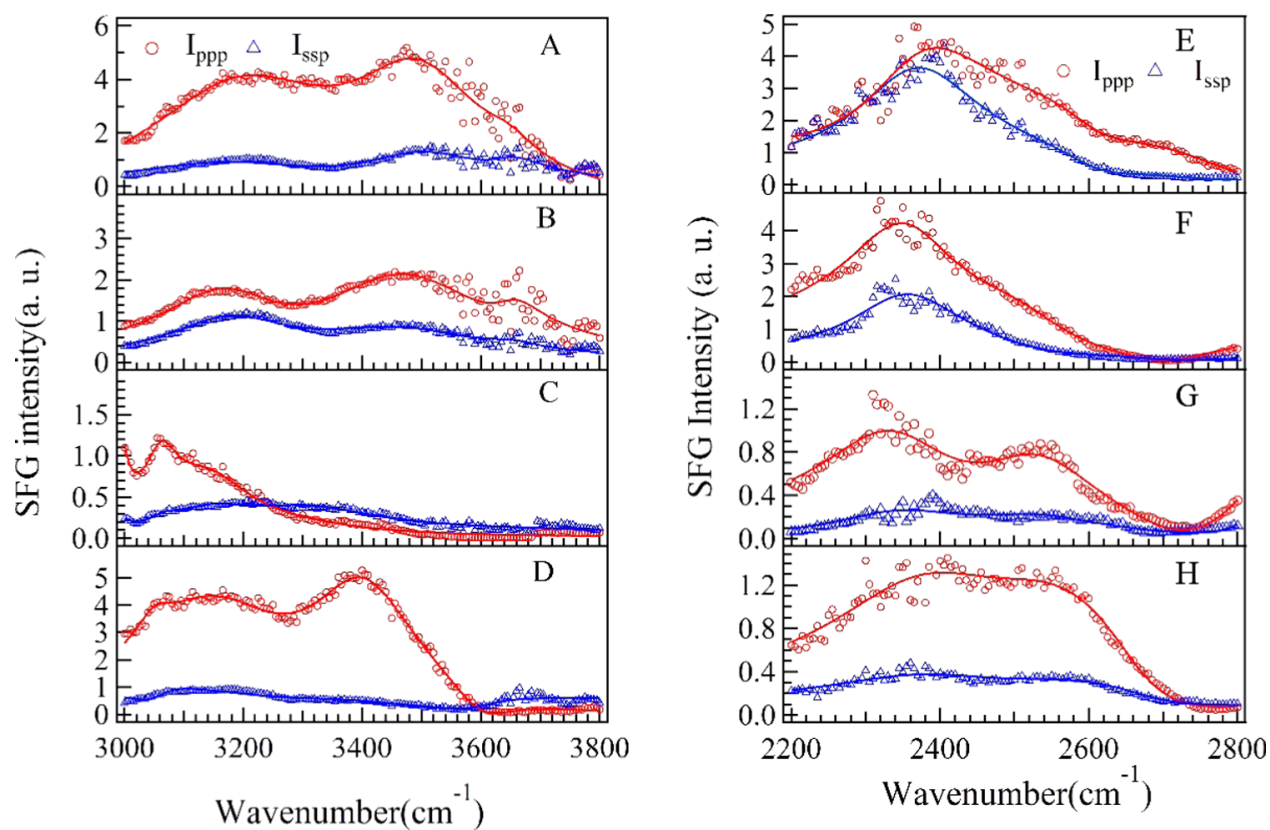

Figure 4. Left: SFG spectra in the wavenumber range of $2800-3800 \mathrm{~cm}^{-1}$ at different concentrations of $\mathrm{dT}_{25} / \mathrm{H}_{2} \mathrm{O}$ solution; $(\mathrm{A}) C_{\mathrm{dT}}=0 \mathrm{nM}$ (bilayer only); (B) $C_{\mathrm{dT}}=25 \mathrm{nM}$; (C) $C_{\mathrm{dT}}=100 \mathrm{nM}$; (D) $C_{\mathrm{dT}}=250 \mathrm{nM}$. Right: SFG spectra in the wavenumber range of $2000-2800 \mathrm{~cm}^{-1}$ at different concentrations of $\mathrm{dT}_{25} / \mathrm{D}_{2} \mathrm{O}$ solution; (E) $C_{\mathrm{dT}}=0 \mathrm{nM}$ (bilayer only); (F) $C_{\mathrm{dT}}=25 \mathrm{nM} ;(\mathrm{G}) C_{\mathrm{dT}}=75 \mathrm{nM} ;(\mathrm{H}) C_{\mathrm{dT}}=250 \mathrm{nM}$.

collected (shown in Figure 4). The concentration dependence of effective polarizabilities of OD stretching $\left(\left|P_{\mathrm{OD}}^{(2)}\right|=\mid A_{\mathrm{ssp}, \mathrm{OD}} /\right.$ $\Gamma \mathrm{l})$ is shown in Figure 6 . The peaks at $\sim 3200, \sim 3400$, and $\sim 3650 \mathrm{~cm}^{-1}$, originated from the $\mathrm{OH}$ stretching modes of surface $\mathrm{H}_{2} \mathrm{O}$ molecules, ${ }^{54,55}$ are shown in the wavenumber range of $3000-3800 \mathrm{~cm}^{-1}$ (Figure $4 \mathrm{~A}$ ). The peaks at $\sim 2350$, $\sim 2550$, and $\sim 2720 \mathrm{~cm}^{-1}$, originated from the OD stretching modes of surface $\mathrm{D}_{2} \mathrm{O}$ molecules, ${ }^{56-58}$ are shown in the wavenumber range of $2200-2800 \mathrm{~cm}^{-1}$ (Figure 4B). SFG-VS intensities of $\mathrm{OH}$ stretching modes and $\mathrm{OD}$ stretching modes can be used as indicators of surface charge density and hydrogen-bonding strength (function S1 in the Supporting Information). The spectra intensities of $\mathrm{OH}$ stretching modes show a drop-then-rise trend with a minimum value at $C_{\mathrm{dT}}=100$ $\mathrm{nM}$, and the spectra intensities of OD stretching modes show a minimum value at $C_{\mathrm{dT}}=75 \mathrm{nM}$ (Figure 5B). As shown in Figure $5 \mathrm{~A}$, the peak width of OD stretching mode is slightly increased at $C_{\mathrm{dT}}=75 \mathrm{nM}$. The SFG-VS signals generated from

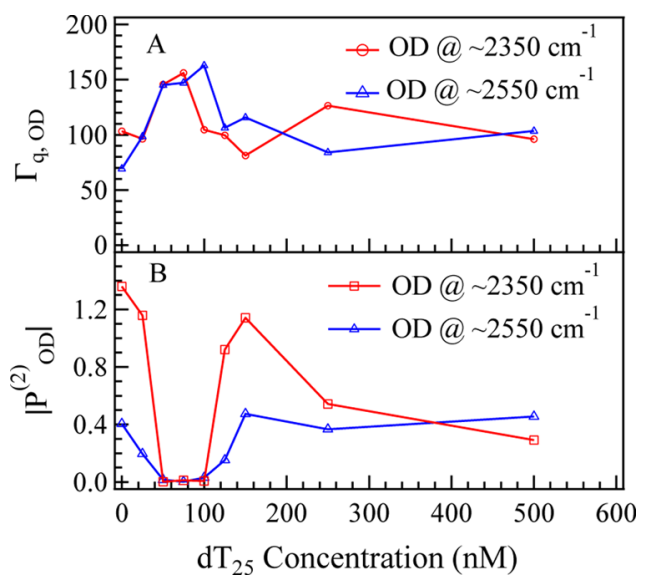

Figure 5. Concentration dependence of $(\mathrm{A})$ peak widths $\left(\Gamma_{\mathrm{q}}\right)$ and $(\mathrm{B})$ effective polarizabilities of OD stretching $\left(\left|P_{\mathrm{OD}}^{(2)}\right|=\left|A_{\mathrm{ssp}, \mathrm{OD}} / \Gamma\right|\right)$. the charged surface have contributions from both the secondorder nonlinear susceptibilities $\chi_{\text {eff }}^{(2)}$ (interface contribution) and third-order nonlinear susceptibilities $\chi_{\text {eff }}^{(3)}$ (bulk contribution).$^{59,60}$ It should be noted that the surface charge can increase not only the molecular ordering of $\mathrm{H}_{2} \mathrm{O} / \mathrm{D}_{2} \mathrm{O}$ molecules, which will increase the interface contribution, but also the surface potential, which will increase the bulk contribution. And the signs of both terms in function S1 are determined by the sign of surface charge $\left(\sigma_{\text {Sum }}=\sigma_{0, \mathrm{DMTAP}}+\right.$ $\left.\sigma_{\mathrm{dT}_{25}}\right)$. Thus, despite the difficulties in quantifying the contribution form the interface and the bulk, combined spectroscopic evidences in OD spectra and $\mathrm{OH}$ spectra indicate that DMTAP bilayer surface reaches a point of zero charge $(\mathrm{PZC})$ at $C_{\mathrm{dT}} \approx 100 \mathrm{nM}^{61-63}$

It is also interesting to see that the adsorption of $\mathrm{dT}_{25}$ molecules continues after the surface reaches PZC at $C_{\mathrm{dT}} \approx 100$ $\mathrm{nM}$. A condensed layer of negatively charged electrolytes can be formed by overcoming repulsive electrostatic forces during the adsorption of $\mathrm{dT}_{25}$ molecules at high concentration $\left(C_{\mathrm{dT}}>100\right.$ $\mathrm{nM}$ ), which is the typical formation of electric double layer of the Gouy-Chapman-Stern model. ${ }^{64,65}$ These newest experimental results indicate that even with the oligonucleotides without conjugated hydrophobic molecular groups, the electrostatic force between the negatively charged oligonucleotide and the positively charged DMTAP bilayer is not the only driven force during the oligonucleotide adsorption. Such conclusion coincides with experimental results of the alkyl chain conjugated oligonucleotides in previous literature works. ${ }^{47}$

2.3. Conformation of $\mathrm{dT}_{25}$ Molecules. Orientation analyses were also performed based on the Raman polarizabilities reported in the literature. ${ }^{6,67}$ Figure $6 \mathrm{~A}, \mathrm{~B}$ shows the calculated tilt angle of in-phase $\mathrm{C}_{4}=\mathrm{O}$ and $\mathrm{C}_{5}=\mathrm{C}_{6}$ stretching mode at $\sim 1660 \mathrm{~cm}^{-1}$ and symmetric $\mathrm{PO}_{2}^{-}$at $\sim 1090 \mathrm{~cm}^{-1}$ at various concentrations. As seen in Figure $6 \mathrm{~A}$, the tilt angle of thymine groups in $\mathrm{D}_{2} \mathrm{O}\left(\theta_{\mathrm{D}_{2} \mathrm{O}}^{\text {Thymine }}\right)$ fluctuates slightly and stays around $70^{\circ}$ when $C_{\mathrm{dT}}$ increases from 25 to $500 \mathrm{nM}$. The final 


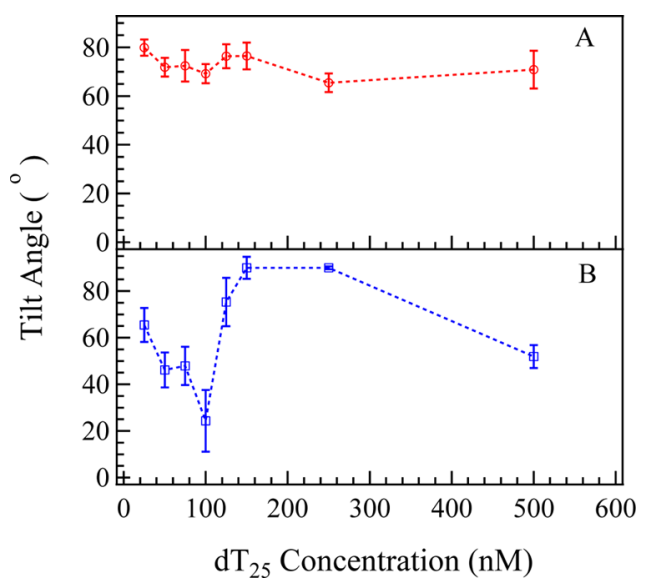

Figure 6. Concentration dependence of calculated tilt angle of $(\mathrm{A})$ inphase $\mathrm{C}_{4}=\mathrm{O}$ and $\mathrm{C}_{5}=\mathrm{C}_{6}$ stretching mode at $\sim 1660 \mathrm{~cm}^{-1}\left(\theta_{\mathrm{D}_{2} \mathrm{O}}^{\text {Thyme }}\right)$ and (B) symmetric $\mathrm{PO}_{2}^{-}$stretching at $\sim 1090 \mathrm{~cm}^{-1}\left(\theta_{\mathrm{D}_{2} \mathrm{O}}^{\mathrm{PO}_{2}^{-}}\right)$in $\mathrm{D}_{2} \mathrm{O}$ solution.

average tilt angle of thymine groups is $70.9 \pm 7.6^{\circ}$ at $C_{\mathrm{dT}}=100$ $\mathrm{nM}$. Such trend of $\theta_{\mathrm{D}_{2} \mathrm{O}}^{\text {Thine }}$ indicates that the tilt angle of thymine groups are insensitive to the changes of surface charge density and surface electrostatic force field. The tilt angle of the symmetric $\mathrm{PO}_{2}^{-}$stretching mode in $\mathrm{D}_{2} \mathrm{O}$ solution $\left(\theta_{\mathrm{D}_{2} \mathrm{O}}^{\mathrm{PO}_{2}^{-}}\right)$ decreases significantly at $C_{\mathrm{dT}}=50$ and $100 \mathrm{nM}$. The decrease of tilt angle and the significant increase of $\chi_{\mathrm{ppp}}^{(2)}$ and $\chi_{\mathrm{ssp}}^{(2)}$ (shown in Figure $3 \mathrm{E}$ ) indicate that the molecular ordering of $\mathrm{PO}_{2}^{-}$groups is greatly improved at $C_{\mathrm{dT}} \approx 100 \mathrm{nM}$.

Both red shifts of symmetric $\mathrm{PO}_{2}^{-}$stretching mode and enhanced ordering of $\mathrm{PO}_{2}^{-}$groups indicate that the binding affinity between DMTAP and $\mathrm{dT}_{25}$ molecules is greatly improved at PZC. Such improved binding affinity may be induced by the significant decrease of electrolyte concentration and ion screening effects around the $\mathrm{PO}_{2}{ }^{-}$groups (in $\mathrm{dT}_{25}$ molecules) and $\mathrm{NH}_{3}{ }^{+}$groups (in DMTAP molecules) at PZC. ${ }^{68,69}$ As estimated by Levinson et al., ${ }^{53}$ the $\mathrm{PO}_{2}{ }^{-}$ symmetric stretching frequency can be tuned by the interaction strength (of various chemical environments) along the $C_{2}$ axis with a rate of $0.40 \mathrm{~cm}^{-1}(\mathrm{MV} / \mathrm{cm})$ via linear Strak effects. The changes of interaction strength $\Delta F$ during the $\mathrm{dT}_{25}-\mathrm{DMTAP}$ bilayer interaction in $\mathrm{H}_{2} \mathrm{O}$ and $\mathrm{D}_{2} \mathrm{O}$ are estimated to be $7.5 \pm$ 1.9 and $15.1 \pm 2.4 \mathrm{MV} / \mathrm{cm}$, respectively, $\left(\Delta F=\frac{\Delta \omega_{0}^{\mathrm{PO}}-\overline{2}}{0.40 \mathrm{~cm}^{-1}(\mathrm{MV} / \mathrm{cm})}\right)$. Thus, the lowest point of $\omega_{0}^{\mathrm{PO}_{2}^{-}}$ curve can be a mark of PZC point of the DMTAP bilayer surface due to the strongest intermolecular interaction at PZC, where the oligonucleotide/lipid charge ratio $=1: 1$. And the $\mathrm{PO}_{2}^{-}$groups of oligonucleotide molecule can act as a sensitive vibration molecular probe ${ }^{68,69}$ for quantifying the oligonucleotide/lipid charge ratio and determining the point of zero charge (PZC) of lipid bilayer surface.

\section{SUMMARY}

In this study, adsorption structure and conformation of oligonucleotide $\left(\mathrm{dT}_{25}\right)$ molecules were investigated by SFGVS in situ. The SFG-VS spectra within different wavenumber ranges were analyzed to provide conformation details of thymine groups, phosphate groups, and $\mathrm{OD} / \mathrm{OH}$ groups and to provide a comprehensive and fundamental understanding of the oligonucleotide adsorption on a model bilayer. Combined spectroscopic evidences also indicate that the formation of an electric double layer on the DMTAP/ $\mathrm{dT}_{25}$ surface follows the Gouy-Chapman-Stern model. And the conformation of $\mathrm{dT}_{25}$ molecules changed significantly when the DMTAP bilayer reaches a point of zero charge $(\mathrm{PZC})$ at $C_{\mathrm{dT}} \approx 100 \mathrm{nM}$. On the basis of the orientation analysis, the final average tilt angle of thymine groups is $70.9 \pm 7.6^{\circ}$. These results demonstrated that the vibrational spectra collected by in situ label-free polarization-resolved SFG-VS detections can provide new molecular insights into the mechanisms of oligonucleotide-membrane interaction.

Our analysis results also show that the symmetric $\mathrm{PO}_{2}{ }^{-}$ stretching mode of oligonucleotide molecules can serve as a sensitive vibration molecular probe to quantify the oligonucleotide/lipid charge ratio and determine the point of zero charge (PZC) of lipid bilayer surface, which may help the researcher to control the layer-by-layer assembly of oligonucleotide-lipid complexes and improve the efficiency of genetic therapy against cancer and viral infections. ${ }^{70,71}$

\section{EXPERIMENTAL SECTION}

Cationic lipid 1,2-dimyristoyl-3-trimethylammonium-propane (DMTAP, purity > 99\%, purchased from Avanti Polar Lipids, Inc.) was used to build solid-supported lamellar lipid bilayers. The DMTAP monolayers were deposited on $\mathrm{CaF}_{2}$ prisms at a surface pressure of $33 \mathrm{mN} / \mathrm{m}\left(\sim 50 \AA^{2} / \mathrm{mol}\right)$ via the Langmuir-Blodgett method. The $\mathrm{CaF}_{2}$ prisms with DMTAP monolayer were slowly dehydrated overnight to remove the residue water and improve the bilayer stability. The second DMTAP monolayer was also deposited on $\mathrm{CaF}_{2}$ prisms at a similar surface pressure $(30-33 \mathrm{mN} / \mathrm{m})$ via the LangmuirSchaefer method to form prism-supported lamellar DMTAP bilayers. The detailed preparation processes can be found in previous papers. ${ }^{72-74}$ The lamellar DMTAP bilayers prepared via the Langmuir-Blodgett and Langmuir-Schaefer methods are highly controllable and repeatable, which can be hardly achieved by the liposomes prepared in solutions. Such bilayer can be used as an ideal model system to investigate the oligonucleotide-membrane interaction.

After the preparation, the lipid bilayers were immersed in a small reservoir with a volume of $2.5 \mathrm{~mL}$. The $\mathrm{dT}_{25}$ oligonucleotide molecules (purity $>98 \%$ by HPLC, Takara Bio, Inc., Dalian) were dissolved in $10 \mathrm{mM}$ tris buffer solution $(\mathrm{pH} \approx 7.4)$ with a concentration of $10 \mathrm{nmol} / \mathrm{mL}(\mu \mathrm{M})$. The $\mathrm{dT}_{25}$-tris solution was added to the reservoir with a microsyringe to interact with the DMTAP bilayers.

All of the SFG-VS measurements were performed on a picosecond sum frequency generation system purchased from EKSPLA, Lithuania. The optical arrangements and programs were custom-modified to perform polarization-resolved detections (see Scheme 1 for details). ${ }^{75,76}$ Briefly, the polarization angle of visible beam $\left(\Omega_{\text {vis }}\right)$ was switched between 0 and $90^{\circ}$ by a rotational motorized half-wave plate (HWP-M) at each wavenumber point during the IR scanning SFG spectra collection. The SFG signals (the ssp and psp signals at $\Omega_{\mathrm{vis}}=$ $0^{\circ}$, the ppp and spp signals at $\Omega_{\mathrm{vis}}=90^{\circ}$, where the first letter $\mathrm{s} / \mathrm{p}$ stands for the polarization state of SFG signal, the second letter stands for the polarization state of visible light, and the third letter stands for the polarization state of IR light) were separated by a polarization splitter (PS). The separated SFG signals passed through Glan polarizers (GP1, GP2), half-wave plates (HWP1, HWP2), notch filters (F1, F2), and focusing 
Scheme 1. Experimental Setup of Polarization-Resolved SFG-VS Detection ${ }^{a}$

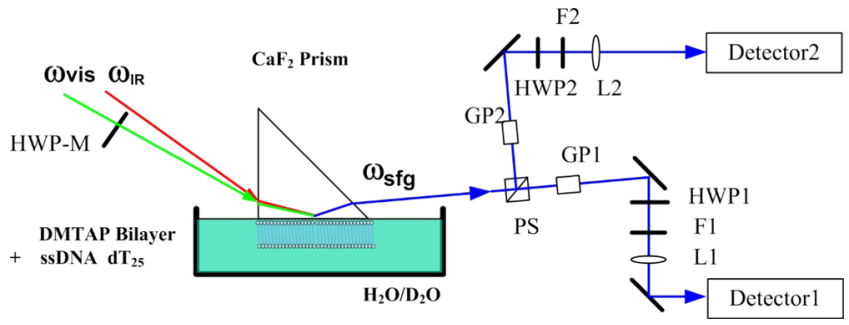

${ }^{a}$ PS: polarization splitter, GP: Glan laser polarizer, HWP: half-wave plate, HWP-M: motorized half-wave plate; F: filter, L: lens.

lenses (L1, L2) separately and then entered two sets of identical detection systems (Monochromator 3501/3504, SOLAR TII and PMT R7899, Hamamatsu). The SFG-VS spectra within the wavenumber ranges of 1000-1200, 15501800 , and $3000-3800 \mathrm{~cm}^{-1}\left(2200-2800 \mathrm{~cm}^{-1}\right.$ for $\mathrm{D}_{2} \mathrm{O}$ solutions) were collected after the sample reached equilibrium. The incident angles of visible beam and IR beam are $63^{\circ}$ and $52^{\circ}$, respectively. Over 150 pulses were averaged for each wavelength point in the SFG-VS spectra. All of the SFG intensities shown in the figures below were normalized by the energy of visible beam $I_{\text {vis }}$ and IR beam $I_{\mathrm{IR}}$. Half of the path of IR beam was purged by $\mathrm{N}_{2}$ gas to decrease the absorbing effects of atmospheric $\mathrm{H}_{2} \mathrm{O}$ and $\mathrm{CO}_{2}$ molecules. The spectra within the wavenumber range of 2200-2800 $\mathrm{cm}^{-1}$ were also normalized to the SFG spectra of z-cut quartz to remove the IR absorbance of atmospheric $\mathrm{CO}_{2}$.

\section{ASSOCIATED CONTENT}

\section{S Supporting Information}

The Supporting Information is available free of charge on the ACS Publications website at DOI: 10.1021/acsomega.7b01214.

Details about the molecular structure of thymidine and tilt angle analysis procedures of SFG data (PDF)

\section{AUTHOR INFORMATION}

\section{Corresponding Authors}

*E-mail: weifeng@jhun.edu.cn (F.W.).

*E-mail: wanquan.zheng77@gmail.com (W.Z.).

ORCID $\odot$

Feng Wei: 0000-0002-3218-5754

Notes

The authors declare no competing financial interest.

\section{ACKNOWLEDGMENTS}

This work was supported by the China National Natural Science Foundation (NSF) (Nos. 21503093 and 61575085) and the Doctorial Program of Jianghan University (No. 10190610001). Dr. W.L. acknowledges the support from NSF of China (No. 21606103). Dr. Cao acknowledges the support from China NSF (No. 51703081), 4th Yellow Crane Talent Programme of Wuhan City (No. 08010004), and National Science and Technology Major Project (No. 2016YFB0401505). The Guassian calculations were carried out at the supercomputing center of the University of Science and Technology of China.

\section{REFERENCES}

(1) Rädler, J. O.; et al. Structure of DNA-Cationic Liposome Complexes: DNA Intercalation in Multilamellar Membranes in Distinct Interhelical Packing Regimes. Science 1997, 275, 810-814.

(2) Braun, C. S.; Jas, G. S.; Choosakoonkriang, S.; Koe, G. S.; Smith, J. G.; Middaugh, C. R. The structure of DNA within cationic lipid/ DNA complexes. Biophys. J. 2003, 84, 1114-1123.

(3) Montis, C.; Sostegni, S.; Milani, S.; Baglioni, P.; Berti, D. Biocompatible cationic lipids for the formulation of liposomal DNA vectors. Soft Matter 2014, 10, 4287-4297.

(4) Ahmed, S.; Savarala, S.; Chen, Y.; Bothun, G.; Wunder, S. L. Formation of lipid sheaths around nanoparticle-supported lipid bilayers. Small 2012, 8, 1740-1751.

(5) Tu, R. S.; Tirrell, M. Bottom-up design of biomimetic assemblies. Adv. Drug Delivery Rev. 2004, 56, 1537-1563.

(6) Unzueta, U.; Saccardo, P.; Domingo-Espín, J.; Cedano, J.; Conchillo-Solé, O.; García-Fruitós, E.; Céspedes, M. V.; Corchero, J. L.; Daura, X.; Mangues, R.; Ferrer-Miralles, N.; Villaverde, A.; Vázquez, E. Sheltering DNA in self-organizing, protein-only nanoshells as artificial viruses for gene delivery. Nanomedicine 2014, 10, $535-541$

(7) Montis, C.; Milani, S.; Berti, D.; Baglioni, P. Complexes of nucleolipid liposomes with single-stranded and double-stranded nucleic acids. J. Colloid Interface Sci. 2012, 373, 57-68.

(8) Dan, N.; Danino, D. Structure and kinetics of lipid-nucleic acid complexes. Adv. Colloid Interface Sci. 2014, 205, 230-239.

(9) Koynova, R.; Wang, L.; Macdonald, R. C. An Intracellular Lamellar-nonlamellar Phase Transition Rationalizes the Superior Performance of some Cationic Lipid Transfection Agents. Proc. Natl. Acad. Sci. U.S.A. 2006, 103, 14373-14378.

(10) Barreleiro, P. C. A.; May, R. P.; Lindman, B. Mechanism of formation of DNA-cationic vesicle complexes. Faraday Discuss. 2003, 122, 191-201.

(11) Barreleiro, P. C. A.; Lindman, B. The Kinetics of DNACationic Vesicle Complex Formation. J. Phys. Chem. B 2003, 107, 6208-6213.

(12) Zhang, Y.; Garzon-Rodriguez, W.; Manning, M. C.; Anchordoquy, T. J. The use of fluorescence resonance energy transfer to monitor dynamic changes of lipid-DNA interactions during lipoplex formation. Biochim. Biophys. Acta, Biomembr. 2003, 1614, $182-192$

(13) Lai, E.; van Zanten, J. H. Real time monitoring of lipoplex molar mass, size and density. J. Controlled Release 2002, 82, 149-158.

(14) Lai, E.; van Zanten, J. H. Monitoring DNA/Poly-l-Lysine Polyplex Formation with Time-Resolved Multiangle Laser Light Scattering. Biophys. J. 2001, 80, 864-873.

(15) Zhang, Y.; Garzon-Rodriguez, W.; Manning, M. C.; Anchordoquy, T. J. The use of fluorescence resonance energy transfer to monitor dynamic changes of lipid-DNA interactions during lipoplex formation. Biochim. Biophys. Acta, Biomembr. 2003, 1614, $182-192$.

(16) Madeira, C.; Loura, L. M.; Aires-Barros, M. R.; Fedorov, A.; Prieto, M. Characterization of DNA/lipid complexes by fluorescence resonance energy transfer. Biophys. J. 2003, 85, 3106-3119.

(17) Pozharski, E. Fluorescence Resonance Energy Transfer-based Analysis of Lipoplexes. Methods Mol. Biol. 2010, 606, 393-398.

(18) Li, A.; Sun, Z.; Ma, Y.; Yang, F.; Ouyang, H.; Yang, X. The Interaction of Recombinant Pseudomonas Aeruginosa Exotoxin A with DNA and Mimic Biomembrane Investigated by Surface Plasmon Resonance and Electrochemical Methods. Talanta 2006, 70, 330-335.

(19) Zhdanov, R. I.; Strazhevskaya, N. B.; Jdanov, A. R.; Bischoff, G. A Spectroscopic and Surface Plasmon Resonance Study of Oleic Acid/ DNA Complexes. J. Biomol. Struct. Dyn. 2002, 20, 231-242.

(20) Huebner, S.; Battersby, B. J.; Grimm, R.; Cevc, G. Lipid-DNA Complex Formation: Reorganization and Rupture of Lipid Vesicles in the Presence of DNA As Observed by Cryoelectron Microscopy. Biophys. J. 1999, 76, 3158-3166.

(21) Battersby, B. J.; Grimm, R.; Huebner, S.; Cevc, G. Evidence for three-dimensional interlayer correlations in cationic lipid-DNA 
complexes as observed by cryo-electron microscopy. Biochim. Biophys. Acta, Biomembr. 1998, 1372, 379-383.

(22) Choosakoonkriang, S.; Wiethoff, C. M.; Anchordoquy, T. J.; Koe, G. S.; Smith, J. G.; Middaugh, C. R. Infrared Spectroscopic Characterization of the Interaction of Cationic Lipids with Plasmid DNA. J. Biol. Chem. 2001, 276, 8037-8043.

(23) Chen, Q.; Kang, X.; Li, R.; Du, X.; Shang, Y.; Liu, H.; Hu, Y. Structure of the Complex Monolayer of Gemini Surfactant and DNA at the Air/Water Interface. Langmuir 2012, 28, 3429-3438.

(24) Benevides, J. M.; Overman, S. A.; Thomas, G. J. Raman, Polarized Raman and Ultraviolet Resonance Raman Spectroscopy of Nucleic Acids and Their Complexes. J. Raman Spectrosc. 2005, 36, 279-299.

(25) Oberle, V.; Bakowsky, U.; Zuhorn, I. S.; Hoekstra, D. Lipoplex formation under equilibrium conditions reveals a three-step mechanism. Biophys. J. 2000, 79, 1447-1454.

(26) Antipina, A. Y.; Gurtovenko, A. A. Molecular Mechanism of Calcium-Induced Adsorption of DNA on Zwitterionic Phospholipid Membranes. J. Phys. Chem. B 2015, 119, 6638-6645.

(27) Sushko, M. L.; Shluger, A. L. DLVO theory for like-charged polyelectrolyte and surface interactions. Mater. Sci. Eng., C 2007, 27, 1090-1095.

(28) Reimer, D. L.; Kong, S.; Bally, M. B. Analysis of Cationic Liposome-mediated Interactions of Plasmid DNA with Murine and Human Melanoma Cells in Vitro. J. Biol. Chem. 1997, 272, 1948019487.

(29) Pires, P.; Simões, S.; Nir, S.; Gaspar, R.; Düzgünes, N.; Pedroso de Lima, M. C. Interaction of cationic liposomes and their DNA complexes with monocytic leukemia cells. Biochim. Biophys. Acta, Biomembr. 1999, 1418, 71-84.

(30) Pozzi, D.; Marchini, C.; Cardarelli, F.; Amenitsch, H.; Garulli, C.; Bifone, A.; Caracciolo, G. Transfection efficiency boost of cholesterol-containing lipoplexes. Biochim. Biophys. Acta, Biomembr. 2012, 1818, 2335-2343.

(31) Henriques, A. M.; Madeira, C.; Fevereiro, M.; Prazeres, D. M. F.; Aires-Barros, M. R.; Monteiro, G. A. Effect of cationic liposomes/ DNA charge ratio on gene expression and antibody response of a candidate DNA vaccine against Maedi Visna virus. Int. J. Pharm. 2009, 377, 92-98.

(32) Shen, Y. R. The Principles of Nonlinear Optics, 1st ed.; Wiley: New York, 1984.

(33) Ye, S.; Wei, F.; Li, H.; Tian, K.; Luo, Y. Structure and Orientation of Interfacial Proteins Determined by Sum Frequency Generation Vibrational Spectroscopy: Method and Application. Adv. Protein Chem. Struct. Biol. 2013, 93, 213-255.

(34) Liu, J.; Conboy, J. C. Direct Measurement of the Transbilayer Movement of Phospholipids by Sum Frequency Vibrational Spectroscopy. J. Am. Chem. Soc. 2004, 126, 8376-8377.

(35) Wang, H. F.; Gan, W.; Lu, R.; Rao, Y.; Wu, B. H. Quantitative Spectral and Orientational Analysis in Surface Sum Frequency Generation Vibrational Spectroscopy (SFG-VS). Int. Rev. Phys. Chem. 2005, 24, 191-256.

(36) Castellana, E. T.; Cremer, P. S. Solid Supported Lipid Bilayers: From Biophysical Studies to Sensor Design. Surf. Sci. Rep. 2006, 61, 429-444.

(37) Wu, F. G.; Yang, P.; Zhang, C.; Li, B.; Han, X.; Song, M.; Chen, Z. Molecular interactions between amantadine and model cell membranes. Langmuir 2014, 30, 8491-4899.

(38) Wu, F. G.; Yang, P.; Zhang, C.; Han, X.; Song, M.; Chen, Z. Investigation of Drug-Model Cell Membrane Interactions Using Sum Frequency Generation Vibrational Spectroscopy: A Case Study of Chlorpromazine. J. Phys. Chem. C 2014, 118, 17538-17548.

(39) Li, B.; Wang, H.-Y.; Feng, P.; Han, X.; Chen, Z.; Lu, X.; Wu, F. G. Qualitative and Quantitative Analyses of the Molecular-Level Interaction between Memantine and Model Cell Membranes. J. Phys. Chem. C 2015, 119, 17074-17083.

(40) Sartenaer, Y.; Tourillon, G.; Dreesen, L.; Lis, D.; Mani, A. A.; Thiry, P. A.; Peremans, A. Sum-Frequency Generation Spectroscopy of DNA Monolayers. Biosens. Bioelectron. 2007, 22, 2179-2183.
(41) Asanuma, H.; Noguchi, H.; Uosalki, K.; Yu, H. Z. Metal Cationinduced Deformation of DNA Self-assembled Monolayers on Silicon: Vibrational Sum Frequency Generation Spectroscopy. J. Am. Chem. Soc. 2008, 130, 8016-8022.

(42) Chen, E. H.; Walter, S. R.; Nguyen, S. T.; Geiger, F. M. Arylsilanated $\mathrm{SiO}_{\mathrm{x}}$ Surfaces for Mild and Simple Two-Step Click Functionalization with Small Molecules and Oligonucleotides. J. Phys. Chem. C 2012, 116, 19886-19892.

(43) Walter, S. R.; Geiger, F. M. DNA on Stage: Showcasing Oligonucleotides at Surfaces and Interfaces with Second Harmonic and Vibrational Sum Frequency Generation. J. Phys. Chem. Lett. 2010, $1,9-15$.

(44) Howell, C.; Schmidt, R.; Kurz, V.; Koelsch, P. Sum-FrequencyGeneration Spectroscopy of DNA Films in Air and Aqueous Environments. Biointerphases 2008, 3, FC47-FC51.

(45) Howell, C.; Zhao, J.; Koelsch, P.; Zharnikov, M. Hybridization in SSDNA Films-A Multi-Technique Spectroscopy Study. Phys. Chem. Chem. Phys. 2011, 13, 15512-15522.

(46) Wurpel, G. W. H.; Sovago, M.; Bonn, M. Sensitive Probing of DNA Binding to a Cationic Lipid Monolayer. J. Am. Chem. Soc. 2007, $129,8420-8421$.

(47) Wei, F.; Tian, K.; Zheng, W. Interfacial Structure and Transformation of Guanine-Rich Oligonucleotides on Solid Supported Lipid Bilayer Investigated by Sum Frequency Generation Vibrational Spectroscopy. J. Phys. Chem. C 2015, 119, 27038-27044.

(48) Zhang, S. L.; Michaelian, K. H.; Loppnow, G. R. Vibrational Spectra and Experimental Assignments of Thymine and Nine of Its Isotopomers. J. Phys. Chem. A 1998, 102, 461-470.

(49) Weng, G.; Chen, C. X.; Balogh-Nair, V.; Callender, R.; Manor, $D$. Hydrogen bond interactions of $\mathrm{G}$ proteins with the guanine ring moiety of guanine nucleotides. Protein Sci. 1994, 3, 22-29.

(50) Scheiner, S.; Čuma, M. Relative Stability of Hydrogen and Deuterium Bonds. J. Am. Chem. Soc. 1996, 118, 1511-1521.

(51) Lucazeau, G.; Guemas, L.; Novak, A. Vibrational spectra and structure of $\mathrm{K}_{2} \mathrm{Zn}\left(\mathrm{NH}_{2}\right)_{4}$ and $\mathrm{Rb}_{2}\left(\mathrm{NH}_{2}\right)_{4}$ amides. Inorg. Chim. Acta 1976, 20, 11-18.

(52) Izzo, V.; Fornili, S. L.; Cordone, L. Thermal denaturation of $B$. subtilis DNA in $\mathrm{H}_{2} \mathrm{O}$ and $\mathrm{D}_{2} \mathrm{O}$ observed by electron microscopy. Nucleic Acids Res. 1975, 2, 1805-1810.

(53) Levinson, N. M.; Bolte, E. E.; Miller, C. S.; Corcelli, S. A.; Boxer, S. G. Phosphate vibrations probe local electric fields and hydration in biomolecules. J. Am. Chem. Soc. 2011, 133, 13236-13239.

(54) Gan, W.; Wu, D.; Zhang, Z.; Feng, R. R.; Wang, H. F. Polarization and experimental configuration analyses of sum frequency generation vibrational spectra, structure, and orientational motion of the air/water interface. J. Chem. Phys. 2006, 124, No. 114705.

(55) Gan, W.; Wu, D.; Zhang, Z.; Guo, Y.; Wang, H. F. Orientation and motion of water molecules at air/water interface. Chin. J. Chem. Phys. 2006, 19, 20-24.

(56) Mondal, J. A.; Nihonyanagi, S.; Yamaguchi, S.; Tahara, T. J. Am. Chem. Soc. 2010, 132, 10656-10657.

(57) Mondal, J. A.; Nihonyanagi, S.; Yamaguchi, S.; Tahara, T. J. Am. Chem. Soc. 2012, 134, 7842-7850.

(58) Sheu, S.-Y.; Schlag, E. W.; Selzle, H. L.; Yang, D.-Y. Molecular Dynamics of Hydrogen Bonds in Protein $-\mathrm{D}_{2} \mathrm{O}$ : The Solvent Isotope Effect. J. Phys. Chem. A 2008, 112, 797-802.

(59) Sovago, M.; Vartiainen, E.; Bonn, M. Observation of buried water molecules in phospholipid membranes by surface sum-frequency generation spectroscopy. J. Chem. Phys. 2009, 131, No. 161107.

(60) Gonella, G.; Lütgebaucks, C.; de Beer, A. G. F.; Roke, S. Second Harmonic and Sum-Frequency Generation from Aqueous Interfaces Is Modulated by Interference. J. Phys. Chem. C 2016, 120, 9165-9173.

(61) Wang, H. F. Sum frequency generation vibrational spectroscopy (SFG-VS) for complex molecular surfaces and interfaces: Spectral lineshape measurement and analysis plus some controversial issues. Prog. Surf. Sci. 2016, 91, 155-182.

(62) Ong, S.; Zhao, X.; Eisenthal, K. B. Polarization of water molecules at a charged interface: second harmonic studies of the silica/ water interface. Chem. Phys. Lett. 1992, 191, 327-335. 
(63) Eftekhari-Bafrooei, A.; Borguet, E. Effect of Electric Fields on the Ultrafast Vibrational Relaxation of Water at a Charged SolidLiquid Interface as Probed by Vibrational Sum Frequency Generation. J. Phys. Chem. Lett. 2011, 2, 1353-1358.

(64) Lis, D.; Backus, E. H.; Hunger, J.; Parekh, S. H.; Bonn, M. Liquid flow along a solid surface reversibly alters interfacial chemistry. Science 2014, 344, 1138-1142.

(65) Oldham, K. B. A Gouy-Chapman-Stern model of the double layer at a (metal)/(ionic liquid) interface. J. Electroanal. Chem. 2008, 613, 131-138.

(66) Grahame, D. C. The Electrical Double Layer and the Theory of Electrocapillarity. Chem. Rev. 1947, 41, 441-501.

(67) Tsuboi, M.; Benevides, J. M.; Thomas, J. G. J. Raman Tensors and their application in structural studies of biological systems. Proc. Jpn. Acad., Ser. B 2009, 85, 83-97.

(68) Kumakura, A.; Tsuboi, M.; Ushizawa, K.; Ueda, T. Polarized Raman spectrum of a single crystal of AZT. Biospectroscopy 1996, 2, 233-242.

(69) Fried, S. D.; Boxer, S. G. Measuring electric fields and noncovalent interactions using the vibrational stark effect. Acc. Chem. Res. 2015, 48, 998-1006.

(70) Ma, J.; Pazos, I. M.; Zhang, W.; Culik, R. M.; Gai, F. SiteSpecific Infrared Probes of Proteins. Annu. Rev. Phys. Chem. 2015, 66, 357-377.

(71) Koltover, I.; Salditt, T.; Safinya, C. R. Phase Diagram, Stability, and Overcharging of Lamellar Cationic Lipid-DNA Self-Assembled Complexes. Biophys. J. 1999, 77, 915-924.

(72) Alhakamy, N. A.; Elandaloussi, I.; Ghazvini, S.; Berkland, C. J.; Dhar, P. Effect of lipid headgroup charge and $\mathrm{pH}$ on the stability and membrane insertion potential of calcium condensed gene complexes. Langmuir 2015, 31, 4232-4245.

(73) Wei, F.; Ye, S.; Li, H.; Luo, Y. Phosphate Ions Promoting Association between Peptide and Modeling Cell Membrane Revealed by Sum Frequency Generation Vibrational Spectroscopy. J. Phys. Chem. C 2013, 117, 11095-11103.

(74) Wei, F.; Li, H.; Ye, S. Specific Ion Interaction Dominates over Hydrophobic Matching Effects in Peptide-Lipid Bilayer Interactions: the Case of Short Peptide. J. Phys. Chem. C 2013, 117, 26190-26196. (75) Wei, F.; Xiong, W.; Li, W.; Lu, W.; Allen, H. C.; Zheng, W. Assembly and relaxation behaviours of phosphatidylethanolamine monolayers investigated by polarization and frequency resolved SFGVS. Phys. Chem. Chem. Phys. 2015, 17, 25114-25122.

(76) Wei, F.; Xia, W. X.; Hu, Z. J.; Li, W. H.; Zhang, J. Y.; Zheng, W. Q. Laser Linewidth and Spectral Resolution in Infrared Scanning Sum Frequency Generation Vibrational Spectroscopy System. Chin. J. Chem. Phys. 2016, 29, 171-178. 